\title{
Road transport infrastructure as a factor of socio-economic territorial development and some aspects of its formation
}

\author{
Andrey Prorokov ${ }^{1, *}$, Tatiana Fonina ${ }^{1}$, and Lyubava Shishova ${ }^{1,2}$ \\ ${ }^{1}$ Moscow Region State University, 24, Vera Voloshina str., 141014, Moscow region, Mytishchi, \\ Russia \\ ${ }^{2}$ Russian University of Transport, 9, bldg. 9, Obraztsova str., 127994, GSP-4, Moscow, Russia
}

\begin{abstract}
The size of the territory of the Russian Federation presupposes the existence and systematic implementation of a long-term program for the country's spatial development, the main element of which is the transport infrastructure. The reorganization of the authorities performing the functions of managing the activities in the field of road transport and road facilities, and the development of strategies for the development of this sector was completed only in the first decade of the 21 st century. The total length of transport routes is 1.7 million $\mathrm{km}$, more than $90 \%$ of which are roads, which determines the importance of road transport and the development of road transport infrastructure. Automobile transport provides not only economic tasks (transports 68\% of cargo), but also solves social issues: it increases the mobility of the population, ensures an increase in well-being (due to the creation of jobs), determines the level of quality of life, ensures territorial accessibility to recreational and healthcare facilities, culture, etc. Nowadays, the domestic fleet of passenger cars is almost 50 million units and continues to grow, but the age structure of the vehicle fleet is deteriorating. The main problems necessary for the implementation of the tasks and ensuring road safety are: expansion and modernization of the road network; provision of transport infrastructure with road facilities, in particular, with service stations in sufficient quantity; improving the quality of service for vehicles and a number of others.
\end{abstract}

\section{Introduction}

Russia is the largest country in the world. The length of the continental territory of Russia from west to east, from Kaliningrad to Chukotka (Cape Dezhnev), is about 10 thousand $\mathrm{km}$. From south to north, from Dagestan to Cape Chelyuskin, the length is 4 thousand $\mathrm{km}$.

Given the size of the country, there are acute problems associated with the spatial accessibility of territories, rational distribution of productive forces, ensuring the uniformity

\footnotetext{
* Corresponding author: doptaganka@yandex.ru
} 
of socio-economic development of regions, and the availability of infrastructure to support transport routes.

Problems associated with accessibility in all corners of the state were recognized even during the time of tsarist Russia. Before the advent of modern modes of transport, when horse-drawn traction served as the main mode of transportation, on the way from Russian capitals to the eastern borders of the empire in the middle of the 18th century, the construction of a route (road) from the European part of Russia through Siberia to the border of China had already begun.

The Siberian tract in its entirety was completed by the middle of the 19th century. Its length from Moscow to Beijing was almost 9 thousand versts ( 1 verst is equal to 1.0668 $\mathrm{km})$. It was the water-land route passing through various settlements. On the land part of the tract, as a road infrastructure, there were post stations for resting travelers and changing horses with an interval of 30 versts. This journey lasted more than one month. The writer A.P. Chekhov, who went from Moscow to Sakhalin in 1890, took three months to reach his destination.

After the launch of the Trans-Siberian Railway in 1905, the journey from Moscow to Vladivostok began to take about 16 days. Nowadays, the train takes 6-7 days, approximately the same amount of time will be needed for motor transport. Air transport covers this distance in 8-9 hours.

However, until now, the problems of the immensity of the territory and insufficient provision of transport infrastructure and roadside infrastructure negatively affect the conditions of the socio-economic development of certain territories and regions of our country. In this regard, it is necessary to expand the network of transport communications, renew the vehicle fleet.

Particular attention should be paid to the construction of highways that ensure the mobility of transport services, as well as road facilities that must ensure the safety of participants and the required operating conditions for vehicles.

\section{Materials and methods}

The country's leadership has always attached particular importance to the issues of spatial development of the territory. In the USSR, the Council for the Study of Productive Forces (CSPF) under the USSR State Planning Committee was directly involved in the issues of an integrated approach to solving this problem. In 1981, one of the authors, while working at the CSPF, participated in the preparation of materials for the Comprehensive Program for the Placement of the USSR's Productive Forces for the period up to 2000.

After the collapse of the USSR, the experience accumulated earlier in long-term comprehensive planning was not in demand during the transition to market relations, but at a certain time the country's leadership realized the need to develop long-term plans for the socio-economic development of the country as a whole, individual regions, and structural sectors of the national economy.

Taking into account the importance of the transport sector in the national economy, after numerous reorganizations of the state administration structure and the next abolition and separation of a number of ministries, a new federal executive body - Federal Road Agency (Rosavtodor) - was formed in 2004. The agency is under the jurisdiction of the Ministry of Transport of the Russian Federation and performs the functions of providing public services, managing state property in the field of road transport and road facilities, including the management of federal highways.

In 2009, the state company Russian Highways (SC Avtodor) was created, which performs the functions of a customer in the design, construction, reconstruction, repair and 
development of roadsides of highways, in terms of roads allocated to it for management (about $3000 \mathrm{~km}$ ).

The functions of these organizations often overlap and duplicate, which creates difficulties in the development of this sector of the economy.

In the message of the President of the Russian Federation to the Federal Assembly in 2005, the need to concentrate state resources on expanding transport, telecommunications and energy infrastructures (including the creation of transcontinental corridors) distant from the center of regions, especially border regions, was noted [1].

In 2014, the Federal Law "On Strategic Planning in the Russian Federation" was adopted, which regulates the relations of all stakeholders in the process of goal-setting, forecasting planning and programming the socio-economic development of the Russian Federation as a whole, its constituent entities and municipalities, sectors of the economy, ensuring national security [2].

On the basis of this law, amendments were made to the Transport Strategy of the Russian Federation for the period up to 2030, developed in 2008. In this Strategy, the priorities for the development of the transport system are highlighted, in particular: balanced development of an efficient transport infrastructure; availability of transport services for cargo owners and population; increasing the level of safety and reducing the harmful effects of transport on the environment [3]. The Transport Strategy for the period up to 2035 is currently being developed.

In developing the tasks of strategic planning of the country's socio-economic development in 2019, the Spatial Development Strategy of the Russian Federation for the period up to 2025 was developed and approved, which defines the goals, objectives and priorities of the country's spatial development. The goal is to ensure sustainable and balanced spatial development of the Russian Federation, aimed at reducing interregional differences in the level and quality of life of the population, accelerating economic growth and technological development, as well as ensuring the national security of the country [4].

The need to speed up the modernization of infrastructure to strengthen the country's connectivity and unleash the potential of the territories was also mentioned in the message of the President of the Russian Federation to the Federal Assembly in 2019 [5].

The solution to the problems of the country's spatial development should be ensured by the formation of an integral transport system and the expansion of the use of all types of transport - rail, sea, air, road.

Of particular importance in the transport sector of the country's national economy is road transport, which primarily provides economic ties within individual territories. This circumstance determines the accelerated development of highways (Table 1).

Table 1. The length of communication lines in the Russian Federation in the period 2005-2019 (thousand $\mathrm{km}$ ) [6].

\begin{tabular}{|l|c|c|c|c|}
\hline & $\mathbf{2 0 0 5}$ & $\mathbf{2 0 1 0}$ & $\mathbf{2 0 1 5}$ & $\mathbf{2 0 1 9}$ \\
\hline $\begin{array}{l}\text { Public railway tracks (operational } \\
\text { length) }\end{array}$ & 85 & 86 & 86 & 87 \\
\hline $\begin{array}{l}\text { Public highways } \\
\text { of them } \\
\text { with hard surface }\end{array}$ & 581 & 825 & 1481 & 1542 \\
\hline Inland waterways & 531 & 665 & 1045 & 1089 \\
\hline
\end{tabular}

From the Federal State Statistics Service (Rosstat) data it is clear that the length of public highways significantly exceeds the length of other transport routes. In recent years, the length of railways and water navigable waterways has almost not increased, while the length of highways is growing. However, it should be noted that since 2010, local roads have been included in the number of roads, and since 2015 - the length of streets. 
Of the total length of public roads, approximately $4 \%$ are federal roads, $33 \%$ are regional and intermunicipal roads, and $63 \%$ are local roads.

With a rather impressive figure of 1.5 million $\mathrm{km}$, the exploited length and quality of highways, taking into account the size of the territory, are insufficient. In China, whose territory is almost two times smaller than the territory of Russia, the length of highways is three times higher than domestic indicators, and in terms of road density, our country corresponds to the level of Uzbekistan (Table 2).

Table 2. Comparative length of highways in Russia and some foreign countries [6].

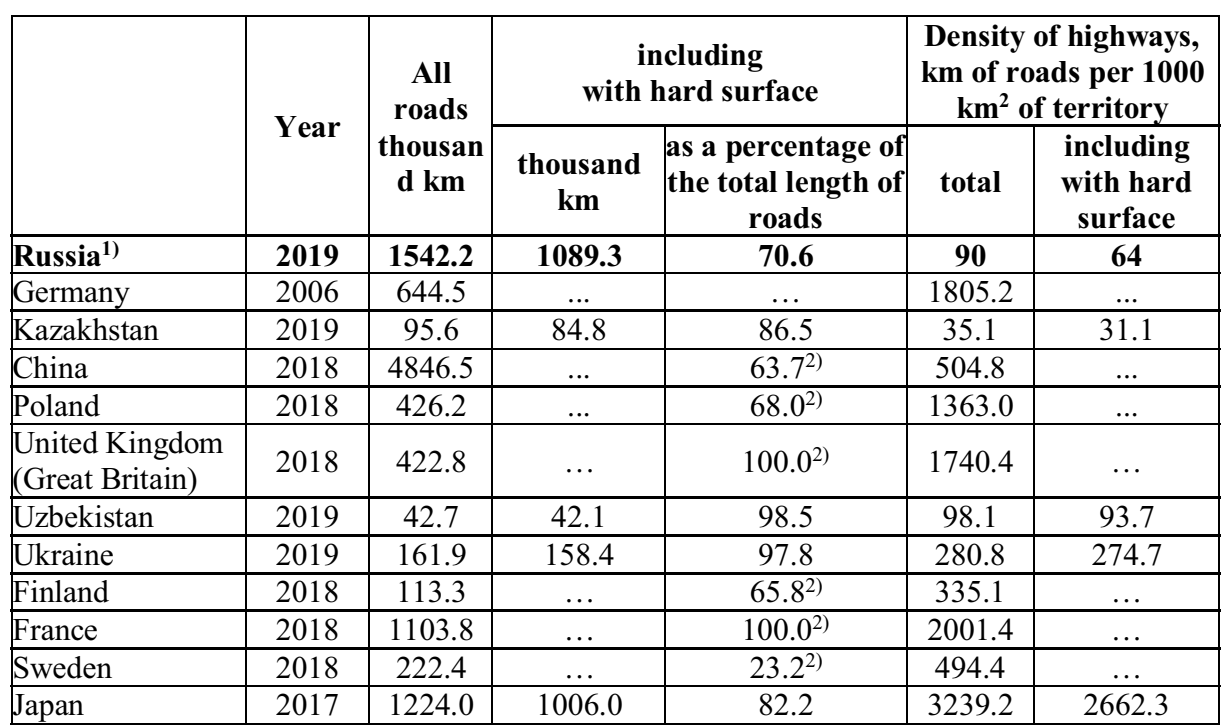

1) In Russia and the CIS member states - public roads.

2) 2011 .

The low density of highways, perhaps, is also the main reason for the relatively low, in comparison with foreign countries, passenger turnover of road transport in Russia (Table $3)$. This, in turn, leads to limited mobility of the population.

Table 3. Passenger turnover of the automobile transport ${ }^{1)}$ (billion passenger-kilometers) [6].

\begin{tabular}{|l|c|c|c|c|c|}
\hline & $\mathbf{2 0 0 5}$ & $\mathbf{2 0 1 0}$ & $\mathbf{2 0 1 5}$ & $\mathbf{2 0 1 7}$ & $\mathbf{2 0 1 8}$ \\
\hline Russia $^{\mathbf{2 3 )}}$ & $\mathbf{1 4 2 . 3}$ & $\mathbf{1 4 0 . 6}$ & $\mathbf{1 2 6 . 3}$ & $\mathbf{1 2 3 . 4}$ & $\mathbf{1 2 2 . 5}$ \\
\hline Germany & 923.9 & 948.8 & 992.1 & 983.0 & 982.7 \\
\hline Italy & 778.0 & 800.6 & 778.9 & 847.6 & 825.9 \\
\hline Kazakhstan & 91.7 & 126.2 & 222.7 & 240.1 & 247.5 \\
\hline China & 929.2 & 1502 & 1074 & 976.5 & 928.0 \\
\hline Netherlands & 153.6 & 149.0 & 144.4 & 143.3 & 150.0 \\
\hline Poland & 201.5 & 230.5 & 238.2 & 241.8 & 247.0 \\
\hline $\begin{array}{l}\text { United Kingdom (Great } \\
\text { Britain) }\end{array}$ & 711.1 & 690.9 & 696.0 & 709.3 & 709.5 \\
\hline USA & 7402 & 7602 & 8049 & 8339 & 8429 \\
\hline Turkey & 195.0 & 226.9 & 290.7 & 305.5 & 317.7 \\
\hline Ukraine & 52.5 & 52.0 & 34.6 & 35.5 & 34.6 \\
\hline France & 754.7 & 749.9 & 780.6 & 800.7 & 814.6 \\
\hline Sweden & 117.2 & 117.4 & 121.7 & 126.1 & 126.0 \\
\hline
\end{tabular}

1) Taxi included.

2) $2019-122.5$ billion passenger-km.

3) Taxi excluded.

4) 2009 . 
Automobile transport is the domestic leader among all types of transport in the transportation of goods, yielding to rail transport in terms of freight turnover (Table 4). This is determined by the difference in the functional purpose of road transport, the use of which is effective when transporting relatively small cargoes and a small number of passengers over relatively short distances. But it is transportations of this kind that are the most numerous and ensure the interaction of business entities and social interaction.

Table 4. Cargo transportation and cargo turnover by type of transport in 2019 [6].

\begin{tabular}{|l|c|c|}
\hline \multicolumn{1}{|c|}{ Kind of transport } & $\begin{array}{c}\text { Cargo transportation } \\
\text { (million tons) }\end{array}$ & $\begin{array}{c}\text { Freight turnover } \\
(\text { bln t } \cdot \text { km) }\end{array}$ \\
\hline Total & $\mathbf{8 4 2 1}$ & $\mathbf{5 6 7 4}$ \\
\hline Railway & 1399 & 2602 \\
\hline Road & 5735 & 275 \\
\hline Pipeline & 1159 & 2686 \\
\hline Water & 127 & 103 \\
\hline Air & 1.3 & 7.4 \\
\hline
\end{tabular}

In the structure of the total volume of transported goods in Russia, the share of road cargo transportation is $68 \%$. Of the total volume of goods transported by road, $27 \%$ is transportation on a commercial basis

According to the registration authorities of the Ministry of Internal Affairs of the Russian Federation, at the beginning of 2020, about 55 million cars were registered, of which $87 \%$ were passenger cars (Table 5). At the same time, $96 \%$ of the total number of passenger cars are owned by citizens.

Table 5. The number of cars registered in Russia (thousand units) [6].

\begin{tabular}{|l|c|c|c|c|}
\hline & $\mathbf{2 0 0 5}$ & $\mathbf{2 0 1 0}$ & $\mathbf{2 0 1 5}$ & $\mathbf{2 0 1 9}$ \\
\hline Trucks & 4848 & 5414 & 6230 & 6540 \\
\hline Buses & 792 & 894 & 873 & 869 \\
\hline Passenger cars & 25570 & 34354 & 44253 & 48430 \\
\hline
\end{tabular}

For the period 2010-2019, the fleet of buses has decreased, the fleet of trucks has increased by $21 \%$, while the fleet of passenger cars has grown by $41 \%$ over the same period and continues to grow. According to the Association of European Businesses, 1.6 million passenger cars were sold in Russia in 2020 [7].

In general, the transport complex of the country provides $6 \%$ of the gross national product (GDP) [8]. In addition, it is a system-forming factor in the spatial development of Russia and should ensure the solution of problems related to the inconsistency of the existing level of development of transport infrastructure with the needs of the economy and population of the constituent entities of the Russian Federation and the country as a whole.

\section{Results}

One of the most important elements of the transport complex is road transport, the predominant share of which is occupied by passenger cars.

Passenger cars are designed to solve not only national economic problems, but also social issues: ensuring the growth of the well-being of the population (due to the creation of jobs), ensuring the mobility of the population, it determines the level of quality of life, ensures territorial accessibility to recreational, healthcare, cultural facilities, etc.

Considering the importance of road transport, it should be noted that in Russia, with a relatively more developed system of public transport, in comparison with foreign countries, not all settlements have regular public transport connections. According to the Ministry of Finance of the Russian Federation, for example, the number of rural settlements served by 
buses in suburban and intercity traffic was 85,904 at the beginning of 2020 , with the total number of these points in the country being 153,510 [9]. Thus, $46 \%$ of rural settlements are not covered by the public transport system. That is why the role of passenger transport and, first of all, owned by citizens, acquires an important social significance.

For the efficient operation of passenger transport, first of all, an extensive network of high-quality highways with an equipped road maintenance system is required. Unfortunately, neither the length of highways, nor their density meet the set tasks of the spatial development of the country.

The Transport Strategy for the period up to 2030 provided for an increase in the length of roads by 1.7 million $\mathrm{km}$.

In 2018, national projects were developed and approved in 12 areas of socio-economic development for the period 2019-2024. One of these projects is "Safe and High-Quality Roads". Within the framework of this project, it is envisaged, in particular, to increase the share of regional highways that meet regulatory requirements in their total length to at least $50 \%$, compared to the indicators of 2017 . It was planned to allocate about 4.8 billion rubles for solving the tasks of this project, $87 \%$ of which - at the expense of the consolidated budgets of the constituent entities of the Russian Federation [10].

Highways, as an object of transport infrastructure, include land plots within the boundaries of the land line and road structures. The designated areas are intended, in particular, for the placement of road service facilities. Such facilities include recreational facilities, gas stations, repair shops, retail and catering facilities, medical centers, communication centers, etc. The number of road service facilities located on federal highways at the beginning of 2020 is given in table 6 .

Table 6. The number of road service facilities located on federal highways ${ }^{*}[6]$.

\begin{tabular}{|l|c|c|c|c|c|c|}
\hline & $\mathbf{2 0 0 5}$ & $\mathbf{2 0 1 0}$ & $\mathbf{2 0 1 5}$ & $\mathbf{2 0 1 7}$ & $\mathbf{2 0 1 8}$ & $\mathbf{2 0 1 9}$ \\
\hline Parking areas & 3207 & 4072 & 4647 & 4403 & 4371 & 4391 \\
\hline Recreation areas with flyover & 628 & 586 & 504 & 536 & 539 & 539 \\
\hline Washing points & 229 & 321 & 295 & 478 & 524 & 582 \\
\hline Retail facilities & 4662 & 4509 & 4366 & 3700 & 3772 & 4033 \\
\hline Public catering facilities & 4019 & 4179 & 3922 & 4268 & 4502 & 4602 \\
\hline Motels, campsites & 475 & 618 & 825 & 834 & 901 & 908 \\
\hline Gas stations & 4350 & 4808 & 4907 & 4960 & 5080 & 5122 \\
\hline Repair shops & 1083 & 1165 & 1108 & 1427 & 1692 & 1511 \\
\hline First aid posts & 517 & 486 & 364 & 383 & 348 & 337 \\
\hline Public toilets & 2517 & 3127 & 3101 & 3445 & 3681 & 3687 \\
\hline Advertising objects & 10856 & 13559 & 10938 & 9857 & 8475 & 7085 \\
\hline Traffic police posts, customs & 594 & 508 & 349 & 289 & 246 & 322 \\
\hline Weight control points & 78 & 67 & 80 & 79 & 80 & 87 \\
\hline Contact points & 914 & 1011 & 1205 & 1213 & 1213 & 1222 \\
\hline Other service objects & 669 & 266 & 582 & 755 & 1246 & 1225 \\
\hline
\end{tabular}

Unfortunately, the statistics only provide data on road service facilities for federal highways, which make up only $4 \%$ of the total length of highways in the Russian Federation. According to Rosavtodor, federal roads are adequately equipped with road safety facilities. There is a developed system for drivers' rest; $15 \%$ of the total number of gas stations in the country are located on these routes. Things are not so good on regional and local roads.

One of the important elements of ensuring reliable road transport is the technical condition of the vehicle itself, the ability to monitor its condition and timely maintenance. This becomes especially important given the age structure of the passenger car fleet (Table 7). 
Table 7. Age structure of passenger cars (as a percentage of the total) [6].

\begin{tabular}{|l|c|c|c|}
\hline & $\mathbf{2 0 1 0}$ & $\mathbf{2 0 1 5}$ & $\mathbf{2 0 1 9}$ \\
\hline Cars in service, years & 100 & 100 & 100 \\
\hline up to 5 & 27.2 & 28.3 & 28.9 \\
\hline $5.1-10$ & 24.5 & 24.8 & 23.5 \\
\hline more than 10 & 48.2 & 46.9 & 47.6 \\
\hline
\end{tabular}

According to the Federal State Statistics Service, almost 50\% of passenger cars in the country have been in operation for more than 10 years. According to the analytical agency Avtostat, which is the leading domestic non-governmental publication in the field of collecting statistics and analyzing the state of the automobile market, the average age of cars in the country is over 12.5 years, while one third of passenger cars are over 15 years old [11].

For comparison, according to Avtostat experts, the average age of a car fleet in European countries is 11.5 years. The youngest fleet of registered passenger cars is in Luxembourg (6.5 years), Great Britain (8 years) and Austria (8.3 years). The oldest cars are registered in Eastern European countries. In Lithuania, Estonia and Romania, for example, the average age of cars is over 16.5 years, in the Czech Republic and Croatia it is about 15 years.

The constant increase in the number of used cars and the high average age of the vehicle fleet determine the need for high-quality maintenance and repair of vehicles.

According to Avtostat, the total demand for car services in 2020 was about 650 billion rubles, excluding the sale of spare parts and consumables (only the cost of work) [12].

According to the analytical agency, car maintenance services are provided in the country by about 76 thousand service stations (there is no official data). In the process of determining the capacity of car services, all service stations (repair shops) are divided into three categories: official dealers (have agreements with the car manufacturer), independent service stations (independently determine the range of services), and highly specialized points (provide 2-3 types of services). Of the total number of service stations, highly specialized (the so-called "garage type") make up almost $60 \%$, official dealers - 5\% [13].

According to experts' calculations, there should be one service station with a full-format service for 100 cars. Based on this, there is a shortage of full-format service stations in the country in the amount of 15-16 thousand units.

\section{Discussion}

Providing the spatial and socio-economic development of the country, road transport, in turn, has a number of negative economic and social consequences.

The operation of vehicles leads to atmospheric and noise pollution of the environment, since it is accompanied by the release of exhaust gases, tire friction products, clutch and brake operation, etc. The deterioration of the environment also entails a worsening of the quality of life of citizens.

Maintenance of vehicles leads to the generation of waste - used batteries, oils, tires, process fluids, old car bodies, etc. The need to collect, transport, store and dispose of such waste, which is generated during the maintenance of vehicles, as well as their repair, causes additional economic costs. Waste itself is a significant threat to the environment, which leads to a decrease in the quality of life of citizens.

In the foreseeable future, there is no reason to expect a radical innovative replacement of existing vehicles. Modernization of vehicles, taking into account modern environmental requirements, is being implemented slowly and with great problems. By the beginning of 2020 , in Russia, the number of passenger cars capable of using natural gas as a motor fuel 
accounted for only $0.02 \%$ of their total number, and the number of electric charging stations consisted of 26 units [6].

The construction and maintenance of regional and local highways is entrusted to the authorities of the corresponding level. Funds for these functions are accumulated in the budgets of the constituent entities of the Russian Federation mainly due to the transport tax, which is the main source of replenishment of road funds. For various reasons (length of roads, insignificant share of tax in the consolidated budget of regions, ineffective spending of funds, arrears, etc.), the volume of these funds is clearly insufficient.

According to the results of the audit by the Accounts Chamber of the Russian Federation of the use of budget funds for the maintenance of federal highways, 128.3 billion rubles was allocated in 2019 , and for the maintenance of the regional road network, which is ten times larger, 146.4 billion rubles. In general, in 2019 , an average of $29.6 \%$ of funds from the normative need were allocated for the maintenance of regional and intermunicipal roads [14].

At the same time, in the national project on safe and high-quality roads, as mentioned above, it is assumed that $87 \%$ of the costs of planned activities will be financed from the consolidated budgets of the constituent entities of the Russian Federation.

An important element of the transport infrastructure and ensuring road safety, taking into account the age structure of vehicles, are road service facilities, in particular, service stations (repair shops).

However, the number of available service stations, their equipment and the quality of service do not meet modern standards. It is difficult to talk about the quality of vehicle maintenance if more than half of the service stations are "garage-type" points.

\section{Conclusions}

The main documents of strategic planning for the spatial and transport development of the country define the main macroeconomic problems, goals, objectives and priorities in these areas.

One of the obstacles to the implementation of the tasks set, primarily at the regional level, is, of course, the lack of funds and the ineffective use of the available ones.

As a possible source of additional funds, it is planned to attract private capital to investment projects in the field of motor transport infrastructure.

An effective option for attracting private investors is proven forms of public-private and municipal-private partnerships.

\section{References}

1. Address of the President of the Russian Federation to the Federal Assembly of 25.04.2005, http://www.consultant.ru/document/cons_doc_LAW_53088/

2. Federal Law of 28.06.2014 No. 172-FZ "On Strategic Planning in the Russian Federation" (as amended on 31.07.2020)

3. Transport strategy of the Russian Federation for the period up to 2030. Approved by the order of the Government of the Russian Federation of November 22, 2008 No. 1734-r (as amended on 12.05.2018)

4. M. Nechaeva, V. Nechaev, A. Mottaeva, E3S Web of Conferences 258, 03011 (2021) https://doi.org/10.1051/e3sconf/202125803011

5. Address of the President of the Russian Federation to the Federal Assembly on 02.20.2019, http://www.kremlin.ru/events/president/news/59863 
6. Transport in Russia. 2020: Statistical collection (Federal State Statistics Service, M., 2020)

7. Russian car market: results of 2020, https://news.drom.ru/82353.html\#: :text=По\%20итогам\%202020\%20года\%20в,отче те\%20Ассоциации\%20европейского\%20бизнеса \%20(АЕБ)

8. The structure of Russia's GDP by industry, data from the Federal State Statistics Service, https://bankiros.ru/wiki/term/struktura-vvp-rossii-po-otraslam.

9. T. Tereshkina et al., IOP Conf. Series: Earth and Environmental Science 90, 012138 (2017) doi:10.1088/1755-1315/90/1/012138.

10. National project "Safe high-quality roads", https://rosavtodor.gov.ru/about/upravleniefda/nacionalnyj-proekt-bezopasnye-i-kachestvennye-avtomobilnye-dorogi.

11. A. Mottaeva, A. Mottaeva, Advances in Intelligent Systems and Computing 1258, 506517 (2021)

12. How much money do Russians spend on car service? https://www.autostat.ru/infographics/46925/

13. There are about 76 thousand car service points in Russia, https://autostatru.turbopages.org/autostat.ru/s/news/37240/

14. P. Katyukha, A. Mottaeva, E3S Web of Conferences 258, 06064 (2021) https://doi.org/10.1051/e3sconf/202125806064 